\title{
Physical activity and the coronavirus pandemic: an urgent time to change the recommendation focus
}

\section{Atividade física e a pandemia de coronavirus: um momento urgente para mudança no foco das recomendações}

\section{AUTHOR'S \\ Luiz Guilherme Grossi Porto ${ }^{1,2}$ (D) \\ Guilherme E. Molina ${ }^{3}$ (D) \\ Victor K. Matsudo ${ }^{4}$ (D) \\ 1 Universidade de Brasília, Faculdade de Educaç̃o Física, Grupo de Estudos em Fisiologia e \\ Epidemiologia do Exercício e da Atividade Física, \\ Brasília, Distrito Federal, Brasil. \\ 2 Harvard T.H. Chan School of Public Health, \\ Boston, Massachusetts, USA. \\ 3 Universidade de Brasília, Faculdade de Educação \\ Física, Grupo de Estudos em Fisiologia \\ Epidemiologia do Exercício e da Atividade Física, \\ Brasília, Distrito Federal, Brasil. \\ 4 Centro de Estudos do Laboratório de Aptidão \\ Física de São Caetano do Sul - CELAFISCS, São \\ Caetano do Sul, São Paulo, Brasil.}

\section{CORRESPONDING}

Luiz Guilherme G. Porto, PhD

luizporto@unb.br

luizggporto@gmail.com

lgporto@bsph.barvard.edu

Universidade de Brasília, Faculdade

de Educação Física (UnB/FEF),

Campus Universitário Darcy Ribeiro, Asa

norte, s/n, Brasília, Distrito Federal, Brasil.

CEP: 70910-900.

DOI

$10.12820 /$ rbafs. $25 \mathrm{e} 0125$

\begin{abstract}
The COVID-19 pandemic is disrupting the routine daily life of millions of people. The pandemic associated restrictive measures impose unprecedented challenges, including the need to stay physically active in a social distancing scenario that drastically reduces access to physical activity (PA) spaces and opportunities. Therefore, we aimed to discuss the need for an urgent change in the main focus of PA recommendations. The total of PA needed for health promotion has been focused on the minimum of $150 \mathrm{~min} /$ moderate-to-vigorous $\mathrm{PA} /$ week. It is time for a call for action toward shifting the focus of PA recommendations. Instead of the traditional "doing at least $150 \mathrm{~min} /$ week of PA, and less than that if you can't reach that goal", recommendations should emphasize the idea of "move more, sit less and, if possible, accumulate $150 \mathrm{~min} / \mathrm{PA} /$ week. The coronavirus pandemic, its associated social distancing and impacts on PA opportunities impose an urgent change in PA recommendation main focus.
\end{abstract}

Keywords: Guidelines; Exercise; COVID-19; Public health; Education.

RESUMO

A pandemia de COVID-19 alterou a rotina de milhóes de pessoas. Medidas restritivas associadas à pandemia impöem desafios sem precedentes, incluindo a necessidade de nos mantermos fisicamente ativos em um cenário de distanciamento social que reduz drasticamente o acesso a espaços e oportunidades de atividade física $(A T F)$. Discutimos a necessidade urgente de mudança no foco das recomendaçôes de ATF. O total de ATF necessária para promoção da saúde tem sido centrado no minimo de 150 min de ATF moderada-vigorosa/sem. É momento para uma chamada de ação em direção à mudança no foco das recomendaçôes. Ao invés do tradicional "acumule pelo menos $150 \mathrm{~min} / \mathrm{ATF} / \mathrm{sem}$, e menos que isso caso não consiga atingir esta meta", as recomendaçôes deveriam enfatizar a ideia de "mexa-se mais - sente-se menos, podendo, acumule $150 \mathrm{~min} / \mathrm{ATF} / \mathrm{sem}$. A pandemia de coronavirus, o distanciamento social e os impactos nas oportunidades de ATF impóem uma mudança urgente no foco das recomendaçôes de ATF.

Palavras-chave: Diretrizes; Exercício; COVID-19; Saúde pública; Educação.

\section{(cc) BY}

This work is licensed under a Creative Commons Attribution 4.0 International License.

\section{Introduction}

The COVID-19 was declared a public health emergency of international concern by the World Health Organization (WHO). This pandemic is disrupting the routine daily life of millions of people worldwide and impacting global physical and mental health. As of Aug 30, 2020, more than 24.8 million people had laboratory-confirmed COVID-19 cases globally ${ }^{1}$. The outbreak is forcing public health agencies and governments to recommend or take preventive measures that may include putting cities on lockdown, closing schools, and avoiding crowded places. Despite the disparity of those measures between countries or regions, social distancing and the "stay home" message have 
been globally recommended. The outbreak itself and its associated restrictive measures impose unprecedented challenges, including the need to stay physically active during this social distancing period. Recent data have shown a plummet in worldwide physical activity $(\mathrm{PA})^{2}$. Even though increased flexibilization of the procedures to control the pandemic has been noted in many countries so far, social/physical distancing recommendations will probably last longer worldwide, mainly for people at high risk of severe COVID-19 and where the number of cases is still growing.

\section{Current PA recommendations and the Coronavirus Pandemic}

Recent papers addressing PA during the coronavirus pandemic highlight a PA level reduction worldwide, as well as overall, anti-inflammatory and immunologic benefits of moderate PA, new challenges, and practical suggestions to be active at home ${ }^{2-4}$. However, the current public health emergency requires a shift in the main focus of PA recommendations. It is time for recommendations to also emphasize the health benefits of doing any PA, even when the amount performed is below the traditional goal of 150 minutes of moderate-to-vigorous PA (MVPA) per week ${ }^{5}$.

Since the first public health recommendation on PA, published in the 90's, the message of 150 minutes/ MVPA/week has been widely disseminated. Many evidence-based documents have been published so far, reinforcing the idea of a minimum of 150 minutes/ MVPA/week. The 2010-WHO recommendations state that "Adults aged 18-64 years should do at least $150 /$ min of moderate-intensity aerobic PA throughout the week..." 6 . The $2^{\text {nd }}$ edition of PA guidelines for Americans, although introducing the concept of "some PA is better than none," states that for substantial health benefits, adults should do at least 150-300 minutes/week of moderate-intensity $\mathrm{PA}^{7}$. There is no doubt about the outstanding scientific quality and relevance of those and other recommendations showing that at least 150 minutes/MVPA/week represents an evidence-based goal to be followed by the general population. However, the focus on the idea of "at least 150 minutes/week for substantial benefits" may discourage those who cannot reach that goal, either because of individual, environmental or socioeconomic factors and/ or due to unexpected and dramatic situations like the coronavirus pandemic.

The WHO is currently conducting an outstanding effort to join up experts to update its guidelines on PA and sedentary behavior. The document draft, available for consultation, albeit emphasizing that "Adults should do at least 150 minutes to 300 minutes of moderate-intensity aerobic physical activity throughout the week...", incorporates, as a conditional recommendation with moderate quality evidence, that "Some physical activity is better than none...", and that if adults are not meeting the above recommendations, "doing some physical activity will bring benefits to health". This draft is dated March 26, a few days after the WHO declared the COVID-19 a global pandemic on March 11.

So, WHO is having a window of opportunity to update its PA and sedentary behavior guidelines while evaluating the effect of the coronavirus pandemic on populations' PA levels and the new sanitary situation that will undoubtedly impact the traditional PA promotion policies. A collective effort from health, educational, PA and sports institutions and expert leaders is needed to avoid physical inactivity and to spread the idea that any PA is better than none ${ }^{3}$. The unpredictable health effects of social distancing and recommendations to avoid crowded places are imposing the need to rethinking PA promotion. Experts need to reevaluate PA promotion strategies and to conduct novel studies to continuously evaluate issues such as efficacy and feasibility in this new public health context. Meanwhile, changing the focus of the main message is supported by evidence showing the health benefits of doing less than the traditional 150 minutes/MVPA/week and the ones that show the impact of the way the message is delivered in human behavior ${ }^{5,7-11}$.

Considering that our society overvalues perfectionism, the idea of some is better than none on a scenario which always highlights the 150 minutes/week as a minimum goal might sound like a consolation prize instead of a positive message. Notably, the guideline produced by the European branch of the WHO for people in self-quarantine without any symptoms or diagnosis of acute respiratory illness states the well-known PA recommendation message (“...150 minutes of moderate-intensity or 75 minutes of vigorous-intensity physical activity per week, or a combination of both"), without making any remark to the health benefits that can be attained with PA performed below those thresholds.

\section{Health-related benefits of PA bellow current recommendations}

An innovative 2016 paper pointed out the lack of a 
minimum PA amount threshold for health benefits ${ }^{5}$. Supported by epidemiological studies, randomized clinical trials, and meta-analyses, the authors underlined that PA-associated health benefits might occur even at remarkably low volumes of PA, not only for healthy individuals but also for people living with chronic diseases. The focus on promoting the health benefits of doing less than 150 minutes/MVPA/week might be especially important for older adults for whom this threshold might be harder to achieve and for whom doing MVPA below current recommendations resulted in a remarkable $22 \%$ reduction in mortality ${ }^{12}$. Also, the older population is at higher risk of COVID-19, and many of them have associated conditions that are associated with insufficient $\mathrm{PA}^{3}$ and, at the same time, increase the risk of more severe cases of COVID-19, such as obesity, diabetes, and hypertension ${ }^{13}$. The benefits of less than 150 minutes/MVPA/week are also readily identifiable in Figure 1, in which a PA correspondent to only $27 \%$ of the target one (150/minutes/ $\mathrm{MVPA} /$ week) results on $50 \%$ of the total reduction of all-cause mortality associated with PA, i.e., an excellent cost-benefit relationship. However, current recommendations keep focusing on the idea that “...for substantial health benefits, adults should do at least 150-300 minutes/week of moderate-intensity PA"?

It is also important to highlight that replacing sedentary time with light-intensity PA is also associated with a mortality reduction ${ }^{7}$. A cohort study has also demonstrated that as few as approximately 4,400 steps/day was associated with a significant reduction in mortality rates among older women ${ }^{8}$.

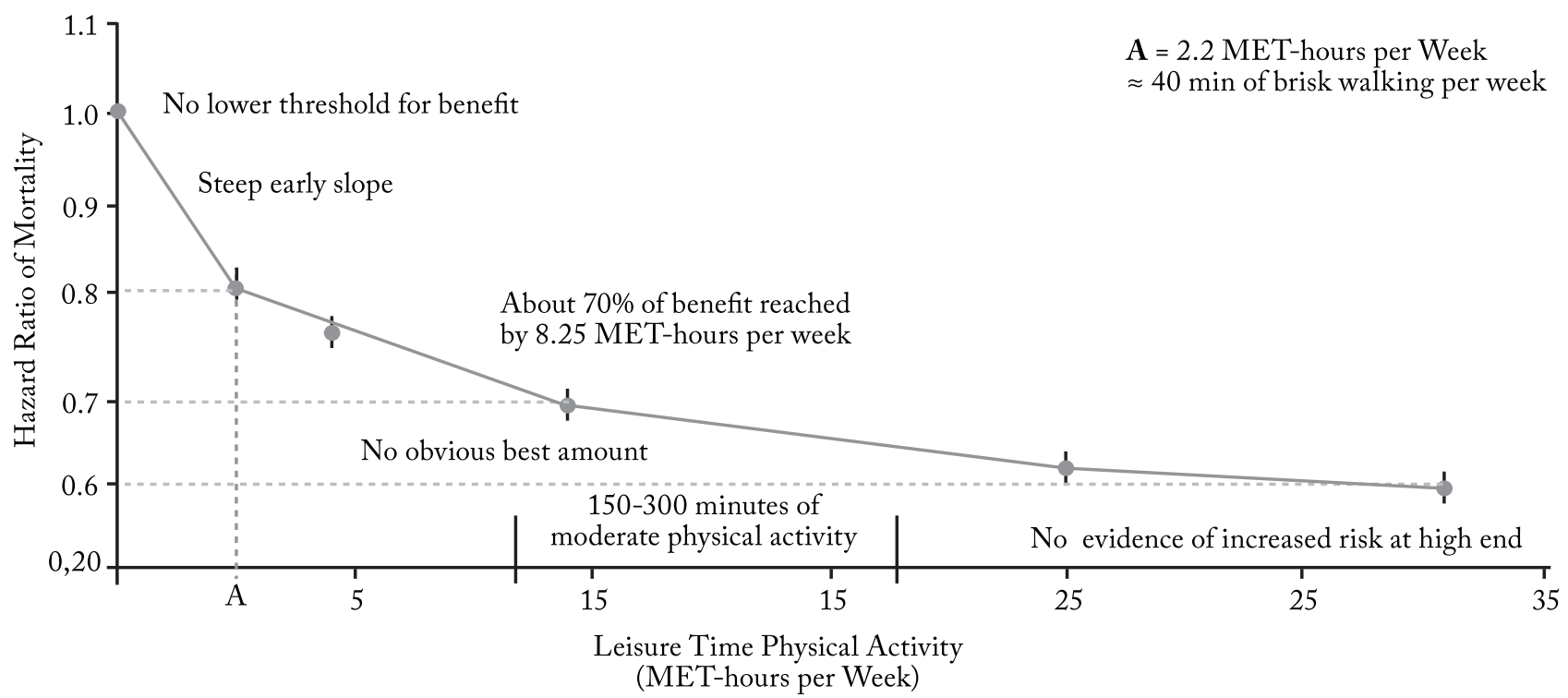

Figure 1 - Relationship of MVPA to all-cause mortality, adapted from the $2^{\text {nd }}$ edition of PA guidelines for Americans ${ }^{7}$
The importance of a recommendation as a tool to motivate people to achieve health-promoting activity levels has been recently pointed out. Recommendations prescribing a lower amount of PA were associated with positive mindsets effect that in turn predicted higher self-efficacy and $\mathrm{PA}^{9}$.

\section{A new approach for PA recommendations for Public Health}

Researches about the influence of the coronavirus pandemic on populations' PA levels are ongoing ${ }^{2,4}$ but it is still too soon to know the exact impact of it, its magnitude, and lasting on the worldwide PA level. However, we are leaving "a tale of two pandemics"14 the 2012-named physical inactivity pandemic and the novel coronavirus one. In other words, this might be a new and powerful syndemic, which is a synergy of epidemics occurring simultaneously in time and place, interacting and producing a complex situation ${ }^{15}$. With the possible negative impact of the latest on the previous one, we will need new and more aggressive strategies to get people active during and after the COVID-19 pandemic ${ }^{3,14}$. Thereafter, we strongly suggest that part of the new effort that needs to be implemented is an adjustment on the message of PA recommendations for public health.

It is necessary to recognize that the choice for the main focus of a public health message is not just a matter of subtlety of writing. The way the message is presented may have a dramatic impact on the target population. The 2002-Nobel Memorial Prize in Economic Sciences, Daniel Kahneman, has pointed out

A = 2.2 MET-hours per Week $\approx 40$ min of brisk walking per week 
the importance of the framing effect on decision making. The way in which a message is presented may enlist different emotions and have a profound impact on one's decision. Using a classic example that describes the odds of a surgery success, one would be much more comfortable when the message is presented as $90 \%$ of success as compared to $10 \%$ of dying one month after the surgery ${ }^{10}$. By analogy, one might be more prone to engage in PA when the message (recommendation) emphasize that any PA is worthy, it is associated with health benefits and much better than none, instead of focusing on a minimum threshold. As stated by Tversky \& Kahneman, "Framing the consequences of a public policy in positive or in negative terms can greatly alter its appeal" ${ }^{11}$. In that sense, WHO launched the \#BeActive and \#HealthyAtHome campaigns to help people to stay active during and after the pandemic, including the importance of having fun and of reducing sedentary behavior. These campaigns, even not calling for changes in WHO PA recommendations, suggest new approaches such as the use of technologies, online classes, break up sitting time, dancing, playing active videogames, and considering PA a way to stay in contact with family and improve mental health.

Thereafter, it is time for a call for action toward shifting the focus of the PA recommendations for public health. Instead of the traditional doing at least 150 minutes/MVPA/week and less than that if you can't reach that goal, PA recommendations should emphasize the idea of move more, sit less and, if possible, accumulate 150 minutes/MVPA/week, highlighting that every step counts. This new emphasis is especially important for disadvantaged populations who have fewer alternatives to do PA at home and the elderly (or any other group at higher risk), to whom the stay home message is strongly recommended. Importantly, people at risk of severe COVID-19 represent a massive part of the population. According to Rezende et al., this proportion in Brazil is estimated from 34.0 to $54.5 \%$ of the nationwide adult population. The authors highlight that their findings "support broad social isolation measures, particularly when testing capacity for SARS-CoV-2 is limited"13.

Essentially, there is no naive expectation that changing the focus of $\mathrm{PA}$ recommendation message will drastically impact on PA promotion. PA is a complex behavior that is influenced by a myriad of individual and social determinants. Also, the probable more important factor that could acutely improve (or restore) populational PA levels is the end or desirable control of coronavirus pandemic, which is certainly more urgent than changing PA message focus. However, and considering that the control of the pandemic is related to social distancing and preventive measures that impose the urgent necessity to rethink PA promotion strategies, the proposed change is plausible, evidence-based, and feasible in a short period of time. Its objective impact on PA level will need further studies.

\section{Final considerations}

In summary, the "stay home" message and all other protective measures recommended by the WHO and other reference institutions require new strategies on how to meet PA guidelines for healthy living. It is necessary to target the less active people and those that might not be able to accumulate 150 minutes/MVPA/ week. Both groups urgently need, more than ever, to be confident that accumulating less than that is worthy and associated with health benefits. There is evidence to support the proposed shift in the message, both from a health perspective, as well as the one from the human decision-making process. Furthermore, other strategies such as the \#BeActive and \#HealthyAtHome WHO's campaigns must be considered toward an active lifestyle, during and after the pandemic.

Therefore, highlighting the message that any PA is good and better than nothing should be considered a priority, in addition to all novelty that specialists and leading institutions like the $\mathrm{WHO}$ are proposing to help the public to stay active during this unprecedented situation. In times of the coronavirus pandemic, isolation, social distancing, and any other circumstances that may prevent people from being more active, this change in the PA recommendation focus is urgent.

\section{Conflict of interest}

The authors declare no conflict of interest.

\section{Author's contributions}

Porto LGG was involved in the conception of the manuscript, drafting, and writing it. Molina GE and Matsudo VK were involved in reviewing the manuscript. All authors were also involved in critical final revision and approval of the correspondence. All authors have read and approved the final version of the manuscript.

\section{References}

1. Coronavirus Disease (COVID-19) Situation Reports [Internet]. 2020 [cited 2020 Aug 31]. Available from: https://www.who.int/emergencies/diseases/novelcoronavirus-2019/situation-reports. 
2. Tison GH, Avram R, Kuhar P, Abreau S, Marcus GM, Pletcher MJ, et al. Worldwide Effect of COVID-19 on Physical Activity: A Descriptive Study. Ann Intern Med. 2020 [cited 2020 Jul 25]. Available from: https://www.acpjournals. org/doi/full/10.7326/M20-2665. [Epub ahead of print].

3. Jurak G, Morrison SA, Leskošek B, Kovač M, Hadžić V, Vodičar J, et al. Physical activity recommendations during the coronavirus disease-2019 virus outbreak. J Sport Health Sci. 2020;9(4):325-7.

4. Sallis JF, Pratt M. Multiple benefits of physical activity during the Coronavirus pandemic. Rev Bras Ativ Fís Saúde. 2020 [cited 2020 Sep 2]. Available from: https://rbafs.org.br/ RBAFS/article/view/14268. [Epub ahead of print].

5. Warburton DER, Bredin SSD. Reflections on Physical Activity and Health: What Should We Recommend? Can J Cardiol. 2016;32(4):495-504.

6. World Health Organization. Global recommendations on physical activity for health. [Internet]. 2010 [cited $2020 \mathrm{Mar}$ 27]. Available from: http://www.ncbi.nlm.nih.gov/books/ NBK305057/.

7. US Office of Disease Prevention and Health Promotion. US Gov. Physical Activity Guidelines [Internet]. 2020 [cited 2020 Mar 27]. Available from: https://health.gov/paguidelines/.

8. Lee I-M, Shiroma EJ, Kamada M, Bassett DR, Matthews CE, Buring JE. Association of Step Volume and Intensity With All-Cause Mortality in Older Women. JAMA Intern Med. 2019 [cited 2019 Jul 28]. Available from: https://jamanetwork.com/journals/jamainternalmedicine/ fullarticle/2734709. [Epub ahead of print].

9. Zahrt OH, Crum AJ. Effects of physical activity recommendations on mindset, behavior and perceived health. Prev Med Rep. 2019 [cited 2020 May 2]. Available from: https:/www.ncbi.nlm.nih.gov/pmc/articles/PMC6948259/. [Epub ahead of print].
10. Kahneman D. Thinking, Fast and Slow. 1st ed. New York: Farrar, Straus and Giroux, 2012.

11. Tversky A \& Kahneman D. Rational Choice and the Framing of Decisions. J Bus. 1986; 59(4):S251-78

12. Hupin D, Roche F, Gremeaux V, Chatard J-C, Oriol M, Gaspoz J-M, et al. Even a low-dose of moderate-to-vigorous physical activity reduces mortality by $22 \%$ in adults aged $\geq 60$ years: a systematic review and meta-analysis. Br J Sports Med. 2015;49(19):1262-7.

13. Rezende LFM, Thome B, Schveitzer MC, Souza-Júnior PRB de, Szwarcwald CL. Adults at high-risk of severe coronavirus disease-2019 (Covid-19) in Brazil. Rev Saúde Pública. 2020 [cited 2020 Jun 8];54. Available from: http://www.rsp.fsp.usp. br/artigo/adults-at-high-risk-of-severe-coronavirus-disease2019-covid-19-in-brazil/?lang=en. [Epub ahead of print].

14. Hall G, Laddu DR, Phillips SA, Lavie CJ, Arena R. A tale of two pandemics: How will COVID-19 and global trends in physical inactivity and sedentary behavior affect one another? Prog Cardiovasc Dis. 2020 [cited 2020 Apr 8]. Available from: https://www.ncbi.nlm.nih.gov/pmc/articles/ PMC7194897/pdf/main.pdf. [Epub ahead of print].

15. Swinburn BA, Kraak VI, Allender S, Atkins VJ, Baker PI, Bogard JR, et al. The Global Syndemic of Obesity, Undernutrition, and Climate Change:The LancetCommission report. Lancet Lond Engl. 2019;393(10173):791-846.

Received: $17 / 08 / 2020$

Approved: 08/09/2020

Quote this article as:

Porto LGG, Molina GE, Matsudo VK. Physical activity and the coronavirus pandemic: an urgent time to change the recommendation focus. Rev Bras Ativ Fis Saúde. 2020;25:e0125. DOI: 10.12820/rbafs.25e0125 